\title{
Impact of Investment Openness on National External Wealth: Based on Valuation Effects Perspective
}

\author{
Kun Liu $\mathbb{D}^{1},{ }^{1}$ Lingchen Lu $\mathbb{D}^{1},{ }^{1}$ and Jianwei $\mathrm{Xu} \mathbb{D}^{2}$ \\ ${ }^{1}$ School of Economics and Management, Fuzhou University, Fuzhou 350108, China \\ ${ }^{2}$ School of Internet Economics and Business, Fujian University of Technology, Fuzhou 350118, China \\ Correspondence should be addressed to Kun Liu; liukun@fzu.edu.cn
}

Received 23 September 2021; Revised 6 December 2021; Accepted 3 January 2022; Published 20 January 2022

Academic Editor: Baogui Xin

Copyright $(0) 2022$ Kun Liu et al. This is an open access article distributed under the Creative Commons Attribution License, which permits unrestricted use, distribution, and reproduction in any medium, provided the original work is properly cited.

In recent years, the rise of investment protectionism has led to the decline of investment openness all over the world. Based on the perspective of valuation effects which affects changes in national external wealth, we carry out empirical analysis and find that investment openness has inhibitory effect on national external wealth in the short term but promotes it in the lag period. Furthermore, we use the open economy macroeconomic theory (NOEM) to construct DSGE model and find that reducing the degree of investment openness will lead to the rise of domestic investment asset prices and produce positive valuation effects, which will lead to the short term increase of national external wealth. However, this effect has poor persistence. In the long run, the reduction of openness will hinder transnational investment, reduce the income of transnational investment, and eventually lead to the deterioration of national external wealth. The DSGE model we constructed can be applicable for solving some problems for open economic policy. From the conclusion we have acquired, it is indicated that nations who want to maintain the steady growth of the external wealth should continue to improve investment openness and international investment environment, alleviate investment information asymmetry, and avert increasing investment protectionism.

\section{Introduction}

The 21st century has seen countries around the world become more deeply integrated into the global economy. However, since 2018, global trade frictions have been escalating, the cost of international trade has been gradually increasing, and a trend of "antiglobalization" is taking shape. With Broadcom's proposed takeover of Qualcomm, Ant Financial's bid for MoneyGram and some other M\&A plans ending unsuccessfully, and the Foreign Investment Risk Review Modernization Act of 2018 (FIRRMA) ${ }^{1}$ coming into force, the trend of "antiglobalization" has begun to extend from international trade to the international investment field. In addition to international trade frictions, the barriers to international investment caused by the mutual increase in investment thresholds between countries have become another important manifestation of the "antiglobalization" trend. According to the Investment Report released by the United Nations Conference on Trade and Development
(UNCTAD),2 the scale of global direct investment has declined sharply in recent years as shown by the continuous decline in global investment openness. In 2018 and 2019, global FDI flows fell by $19 \%$ and $20 \%$, respectively, and in 2020 it is expected to drop by $40 \%$ year-on-year. Apart from the impact of global public health emergencies in 2020, the decline in international investment openness was an important reason that slowed down the process of investment globalization.

The degree of investment openness is mainly affected by the restrictions on transnational investment, which can be caused by information asymmetry in culture, politics, and other aspects between the investor and the investee or by the protectionism of the investor; the former obstacle is objective while the latter is subjective [1]. In recent years, with the development of information technology, the negative impact of information asymmetry on the degree of investment openness is weakening, while the rise of protectionism hinders the increase in investment openness. According to 
the sixth edition of the Balance of Payments Manual, national external wealth is mainly composed of the net foreign assets of nations in the international investment position, which symbolizes the external economic strength of a country and also guarantees the solvency of a country [2]. From the perspective of the United States, due to its chronic trade deficit, it has been burdened with large external debt, leading to a continuous decrease in its external wealth and the weakening of its economic system. It is reasonable to infer that the starting point of the promulgation of FIRRMA is to increase the threshold of foreign investment and reduce the degree of investment openness so as to generate a certain scale of income from foreign investment, which is ultimately conducive to promoting the growth of its external wealth and alleviating the foreign debt problem that has been plaguing the US for years ${ }^{3}$. Therefore, the US has gradually taken the initiative to raise the threshold of investment in recent years. However, a country's unilateral increase in investment thresholds due to protectionism will inevitably lead to a mutual increase in investment thresholds, thereby reducing the degree of bilateral investment openness. Whether this will ultimately help optimize national external wealth has not yet been uniformly explained by academics. Focusing on the above issues, this paper intends to start by examining the composition of national external wealth and using the new open economy macroeconomics (NOEM) analysis paradigm to reveal the dynamic mechanism between the investment openness and national external wealth.

According to the accounting principle of international investment position, national external wealth is not only affected by the current account generated by the gains and losses of international trade and investment but is also affected by the valuation effects generated by the fluctuation of stock asset prices. The former and latter affect the flow and the stock of external wealth, respectively. With the expansion of investment scale in the world, valuation effects are gradually increasing their influence on the national external wealth [3-6]. In recent papers, valuation effects have become an important extension of the theory of external adjustment and are considered as a main influential factor for changes in the national external wealth $[7,8]$. In recent years, although the United States is running a continuous trade deficit, the positive valuation effects have been helpful to its external wealth. On the contrary, China is running a continuous trade surplus, but the negative valuation effects are hurting its external wealth. Furthermore, the difference in the rate of return between external assets and liabilities due to the matching of asset liability structure has led to the shrinkage of external wealth. Therefore, utilizing the valuation effects to examine the dynamic adjustment and adjustment mechanism of external wealth of nations, and then analyzing the dynamic impact of a country's openness on its external wealth, will complete the analysis results.

With the advancement of economic globalization, the scale of outward foreign direct investment in many emerging market countries began to grow steadily. Taking China for example, the outward foreign direct investment stock of China has reached US\$2.19 trillion at the end of 2019 and is now the third largest in the world. However, as the scale of investment increases, investment protectionism is on the rise again, and trade frictions between China and developed countries such as Europe and the US are frequently occurring. Not only has this hindered Chinese companies' overseas investment and M\&A plans, but many overseas investment projects are also facing the risk of loss due to excessive investment costs. Clearly, investment openness has an increasing impact on economic interests of countries with large investment aboard. Therefore, exploring the effect and mechanism of investment openness on external wealth of nations will help countries formulate more appropriate foreign economic policies, to achieve the goal of maintaining and increasing external wealth in the new international economic and trade environment, and help develop a modernized economy and promote high-quality development [9].

The research has been structured as follows. Section 2 summarizes the research status of the existing literature. Section 3 uses statistical data from major countries in the world to construct an empirical analysis model to examine the correlation between a country's degree of investment openness and its external wealth. In Section 4, we build the dynamic stochastic general equilibrium model (DSGE) based on the NOEM analysis paradigm and then explore the dynamic influential mechanism of investment openness on external wealth of nations. Finally, based on the empirical results, policy recommendations for optimizing national external wealth are proposed to provide theoretical support for economies who committed to international investment.

\section{Literature Review}

Research on economic and trade openness has a long history. However, before the 21st century, the research mainly focused on trade openness, and international economic and trade frictions were also mainly reflected in trade frictions. Investment openness has not received sufficient attention in relevant research on the international economy. For example, in the classic transnational trade model constructed by Obstfeld and Rogoff [10], the impact of investment openness was ignored on the assumption that there was no difference in assets flowing across countries and that crossborder investment is barrier-free. Since the 21st century, with the acceleration of the global economic integration process, the scale of transnational investment expanded rapidly. However, obstacles and restrictions on transnational investment have also gradually increased due to information asymmetry between countries and investment protectionism, and the degree of investment openness has become one of the most important factors in the transnational investment and globalization process [11]. As the theoretical model constructed by Obstfeld and Rogoff [10] does not consider the degree of international investment openness, its prediction deviated significantly from the actual economy. Caballero et al. [12] first considered the investment openness factors that affect the cross-border flow of assets based on the model of Obstfeld and Rogoff [10]. Therefore, their economic theoretical model can better explain the differences in asset allocation between countries. Since then, many studies 
have regarded the degree of investment openness as an important factor to consider in research on international economic theory. The degree of international investment openness has been widely considered when analyzing crossborder asset flows [13-17].

As the degree of investment openness has received more attention, research on its causes and economic consequences have also improved. Through empirical analysis, Gourinchas and Rey [18] and Curcuru et al. [19] found, for the first time, that the decline in investment openness caused by information asymmetry between the US and emerging market countries is ultimately due to the difference in the degree of financial market development between the two. This conclusion is also confirmed by the empirical results of many studies $[20,21]$. In addition, research on the economic consequences of investment openness shows that the asymmetry of investment information and the investment barriers caused by protectionism are the main factors that lead to a reduction in the degree of investment openness [11, 14, 22-24]. However, as mentioned above, research on the impact of openness on national external wealth is still rare. Benigno and Romei [25] established a DSGE model to analyze the impact of investment openness on the current account and studied for the first time the relationship between investment openness and the national external wealth. However, in their research, the composition of the changes in external wealth only covers the current account, and the impact of stock asset market value fluctuations on the changes in external wealth was ignored, so their research is still not comprehensive.

National external wealth will be affected not only by the current account flow generated by international trade and international investment gains and losses, but also by changes in the market value of stock assets caused by exchange rate or asset price fluctuations. Lane and MilesiFerretti [26] define the latter as valuation effects. In the 21st century, the scale of the stock of external assets in each country has continued to expand, and the study of valuation effects has gradually become an important expansion of NOEM. By reviewing previous empirical studies [27-31], we find that the influence of valuation effects on external wealth is increasing year by year. Therefore, incorporating valuation effects into the study of national external wealth research can make the conclusions more comprehensive $[6,32]$.

Existing literature shows that the degree of investment openness is an important indicator of the degree of economic globalization. In recent years, academics have made some achievements in research on the factors and economic consequences of investment openness. However, there is no unified explanation on the impact of investment openness on national external wealth. In addition, existing research is not comprehensive because it ignores the impact of valuation effects. Therefore, this study starts with the valuation effects, based on the DSGE model under the NOEM analysis paradigm, and uses empirical analysis to examine the impact of investment openness on national external wealth.

\section{Empirical Analysis}

According to the studies of Lane and Milesi-Ferretti [26] and the IMF (2005), the changes in national external wealth are composed of the valuation effects representing the change in stock assets value and international trade representing the increase and decrease of wealth flow, which can be expressed as $\mathrm{NFA}_{t+1}-\mathrm{NFA}_{t}=\mathrm{VA}_{t}+\mathrm{CA}_{t}$.

$N F A$ represents the stock value of national external wealth, VA represents the valuation effects caused by the fluctuation of the market value of the external stock assets, and $C A$ represents the current account generated by the gains and losses of international trade and investment.

According to previous research [14, 23, 24], when a country unilaterally increases investment restrictions due to protectionism, it is bound to cause a counterattack and ultimately leads to a decline in the degree of bilateral investment openness. In addition, barriers in information transmission, cultural exchanges, and trade contacts between the two sides will also lead to a decline in the degree of bilateral investment openness. The degree of investment openness is a key indicator to measure a country's degree of globalization [33]. Therefore, the following section describes the construction of an empirical analysis model, combined with the valuation effects $(V A)$ and international trade $(C A)$, which are the two factors that constitute the changes in national external wealth, to examine the impact of investment openness on national external wealth.

3.1. Selection and Processing of Empirical Data. To be representative, this part selects the world's 10 largest economies as the source of cross-sectional data, including developed economies such as the US, Japan, Eurozone, Britain, Canada, and Australia and emerging market economies such as China, India, Brazil, and Russia. The regression equations are established as follows:

$$
\begin{array}{r}
n f a_{i, t}=\beta_{1} F O_{i, t}+\beta_{2} X_{i, t}+\mu_{i}+v_{t}+\varepsilon_{i, t}, \\
v a_{i, t}=\beta_{1} F O_{i, t}+\beta_{2} X_{i, t}+\mu_{i}+v_{t}+\varepsilon_{i, t} \\
c a_{i, t}=\beta_{1} F O_{i, t}+\beta_{2} X_{i, t}+\mu_{i}+v_{t}+\varepsilon_{i, t} .
\end{array}
$$

In the equations, $n f a_{i, t}$ is the changes in national external wealth with standardized GDP, $v a_{i, t}$ is the valuation effects with standardized GDP, which represents the stock value changes in national external wealth caused by fluctuations in exchange rate or asset price, and $c a_{i, t}$ is the current account with standardized GDP, which represents the flow changes in national external wealth caused by the gains and losses of international trade and investment. The subscript " $i$ " represents different economies, subscript " $t$ " represents time, $\mu$ represents the national fixed effect, $v$ represents the time fixed effect, and $\varepsilon$ represents the random error term. 
To reduce the endogeneity of the empirical analysis, control variables were introduced and represented by $X_{i, t}$, including per capita GDP $(g d p)$ and trade openness $(T R)$ related to investment openness so as to reduce the influence of economic scale and trade openness on the regression conclusion. In addition, according to the international economic theory model described by Coeurdacier et al. [34] and the real business cycle theory, shocks on the business cycle are an important driving factor of dynamic adjustment, and the valuation effects and trade balance that constitute the changes in national external wealth will also be affected by the impact of the business cycle. To further reduce the endogeneity problem, this study estimates the relative technological innovation shocks of each country or region, represented by $z$, to reflect the business cycle shocks and control them.

All variables are set to the period from 2000 to 2019. The interpretation and processing of each variable are shown in Table 1.

The descriptive statistical results of each variable are shown in Table 2. It can be seen that the data distribution of the variables has significant differences. Furthermore, by determining the optimal lag length using AIC, BIC, and HQIC, we find that the optimal lag lengths for key independent variable investment openness (FO) and control variable trade openness $(T R)$ are both 1 period. Therefore, we add variables $L-F O$ and $L-T R$ to the empirical regression equation to reflect the influence of the related variables on the dependent variables in the optimal lag period.

3.2. Analysis of Empirical Results. Regression equations (1)(3) were performed using the ordinary least squares (OLS) and panel-corrected standard errors (PCSE) estimations. The empirical results are presented in Table 3. Having variables per capita GDP, degree of trade openness, and technological impact, and the time and region controlled, the regression results in column (1) suggest that the degree of investment openness shows a significant negative correlation with external wealth at sight, indicating that the immediate decrease in investment openness can promote the stock value of external assets. However, in 1 lag period, the degree of investment openness is positively correlated with external wealth, suggesting that the decrease in the degree of investment openness is not conducive to the stock value improvement of external assets in the long run. Clearly, the impact of investment openness on national external wealth through valuation effects is quite opposite in the short term and in the long term. In addition, the absolute value of the effect of investment openness on the valuation effects in the lag period is weaker than that at sight.

Further, the regression results in column (2) show that the reduction of investment openness will lead to positive valuation effects in the short term but negative valuation effects in the lag period. Because valuation effects are one of the components of $n f a$ changes, it can be inferred that under the impact of investment openness the change of valuation effects can become the key factor leading the changes in national external wealth from the absolute values in columns (1) and (2).

In addition, according to the regression results in column (3), changes in investment openness have no significant influence on current account, while trade openness has a positive effect on current account changes in the lag period. However, combined with the results shown in columns (1) and (2), we find that the increase of trade openness would have an adverse impact on the valuation effects and further hinder growth of national external wealth.

3.3. Robustness and Endogeneity Test. To check the robustness of the empirical results, this study introduces the financial globalization index of the KOF Globalisation Index designed by Gygli et al. [33] as the alternative variable of investment openness (KOFFI) in performing a robustness test. The results in columns (4) and (5) show that the alternative variable (KOFFI) has a similar effect on national external wealth as the independent variable investment openness, as shown in columns (1) and (2). Therefore, the empirical analysis results are stable.

Further, although we design three control variables that affect national wealth and have time and region controlled, the endogenous problem that there may be a correlated relationship between the degree of investment openness and national external wealth remains. Therefore, this study uses the Index of Economic Globalisation (KOFecgldj) and the Index of Information Globalisation (KOFingldj) as instrumental variables to test endogeneity. Among them, the Index of Economic Globalisation (KOFecgldj) reflects international investment restrictions, international investment agreements, and opening agreements, and the Index of Information Globalisation (KOFingldj) reflects the degree of media and Internet accessibility. As the reduction of investment restrictions and the improvement of information exchange reduce investment barriers and directly improve the degree of investment openness, while the impact on national external wealth is not direct, these two variables are appropriate instrumental variables.

The test results are shown in Table 4 . From the test result of Stage 1, it is found that the information globalization and economic globalization would improve investment openness. But from the test result of Stage 2, it is found that the investment openness of current period (FO) which has been improved by information globalization or economic globalization has a negative effect on growth of national external wealth, and the investment openness of lag period ( $L-F O$ ) has a positive effect on growth of national external wealth. So based on the results of instrumental variable test, it can be seen that the increase in investment openness caused by the reduction of investment restrictions and the improvement of information exchange is not conducive to growth of the external wealth in the short term but can promote growth of the external wealth in the long term. This conclusion is consistent with the regression results shown in Table 4. Therefore, there is no endogenous problem of causality inversion in this empirical result. 
TABLE 1: Empirical variable processing methods and data sources.

\begin{tabular}{|c|c|c|c|c|}
\hline Variable & & Variable definitions & Processing method & $\begin{array}{c}\text { Data } \\
\text { source }\end{array}$ \\
\hline \multirow{3}{*}{$\begin{array}{l}\text { Dependent } \\
\text { variable }\end{array}$} & $n f a$ & Changes in national external wealth & According to IMF (2005), $n f a=v a+c a$ & $\begin{array}{c}\text { EWN } \\
\text { database }^{4}\end{array}$ \\
\hline & $v a$ & $\begin{array}{l}\text { The valuation effects, which represent } \\
\text { the stock value changes in national } \\
\text { external wealth }\end{array}$ & $\begin{array}{l}\text { The valuation effects are divided by dollar-denominated } \\
\text { PPP GDP }\end{array}$ & $\begin{array}{c}\text { EWN } \\
\text { database }\end{array}$ \\
\hline & $c a$ & $\begin{array}{l}\text { The current account, which represents } \\
\text { the flow value changes in national } \\
\text { external wealth }\end{array}$ & $\begin{array}{l}\text { The current account is divided by dollar-denominated PPP } \\
\text { GDP }\end{array}$ & $\begin{array}{l}\text { OECD } \\
\text { database }\end{array}$ \\
\hline $\begin{array}{l}\text { Independent } \\
\text { variable }\end{array}$ & $F O$ & The degree of investment openness & $\begin{array}{l}\text { As noted in Lane and Milesi-Ferretti [35], degree of } \\
\text { investment openness is expressed as (FDI and EQ } \\
\text { assets + liabilities)/GDP, taken natural logarithm }\end{array}$ & $\begin{array}{c}\text { EWN } \\
\text { database }\end{array}$ \\
\hline \multirow{3}{*}{ Control variable } & $z$ & Technological innovation shock & $\begin{array}{l}\text { Use the Cobb-Douglas production function to } \\
\text { approximate total factor productivity (TFP), and the } \\
\text { relative technological innovation shock is represented as } \\
\text { the TFP difference between domestic and foreign countries }\end{array}$ & $\begin{array}{l}\text { OECD } \\
\text { database }\end{array}$ \\
\hline & $T R$ & The degree of trade openness & $\begin{array}{l}\text { As noted in Lv et al. [36], trade openness could be } \\
\text { represented as (import of goods and services + export)/ } \\
\text { GDP, taken natural logarithm }\end{array}$ & $\begin{array}{l}\text { OECD } \\
\text { database }\end{array}$ \\
\hline & $g d p$ & Per capita GDP (PCGDP) & Dollar-denominated per capita PPP GDP & $\begin{array}{l}\text { OECD } \\
\text { database }\end{array}$ \\
\hline
\end{tabular}

TABle 2: Descriptive statistical results.

\begin{tabular}{|c|c|c|c|c|c|}
\hline Variable & Observations & Mean & Std. Dev. & Minimum & Maximum \\
\hline$n f a$ & 200 & -0.0016 & 0.0745 & -0.2214 & 0.2817 \\
\hline$v a$ & 200 & -0.0013 & 0.0751 & -0.1799 & 0.3339 \\
\hline$c a$ & 200 & -0.0004 & 0.0386 & -0.0692 & 0.1804 \\
\hline fo & 200 & -0.1747 & 0.8249 & -2.4480 & 1.5167 \\
\hline$t r$ & 200 & -0.8720 & 0.3478 & -1.5768 & -0.1644 \\
\hline$z$ & 200 & 0.1471 & 0.9605 & -2.0438 & 1.4711 \\
\hline$g d p$ & 200 & 0.7332 & 1.4507 & -2.1949 & 2.2535 \\
\hline
\end{tabular}

TABLE 3: Regression estimation results.

\begin{tabular}{|c|c|c|c|c|c|}
\hline & (1) & (2) & (3) & (4) & (5) \\
\hline & $n f a$ & $v a$ & $\mathrm{ca}$ & $n f a$ & $v a$ \\
\hline$\overline{F O}$ & $-0.2155^{* * *}(-9.48)$ & $-0.2127^{* * *}(-8.99)$ & $-0.0028(-0.41)$ & & \\
\hline$L-F O$ & $0.1292^{* * *}(5.32)$ & $0.1291^{* * *}(5.18)$ & $-0.0001(-0.02)$ & & \\
\hline KOFFI & & & & $-0.3631^{* * *}(-3.26)$ & $-0.3505^{* * *}(-3.09)$ \\
\hline$L-K O F F I$ & & & & $0.2156^{* * *}(2.06)$ & $0.2438^{* *}(2.30)$ \\
\hline$z$ & $0.2549(0.34)$ & $-0.0700(-0.87)$ & $0.0955^{* * *}(4.34)$ & $0.1176(1.02)$ & $0.0083(0.07)$ \\
\hline$g d p$ & $-0.0440(-0.99)$ & $0.01324(0.27)$ & $-0.0572^{* * *}(-4.46)$ & $-0.0518(-0.67)$ & $0.0057(0.307)$ \\
\hline TR & $0.1219^{* *}(2.04)$ & $0.1040^{*}(1.78)$ & $0.0179(0.95)$ & $0.2039^{* * *}(2.68)$ & $0.1820^{* *}(2.32)$ \\
\hline$L-T R$ & $-0.0824^{*}(-1.69)$ & $-0.1371^{* * *}(-2.82)$ & $0.0547^{* * *}(3.28)$ & $-0.1934^{* * *}(2.86)$ & $-0.2529^{* * *}(-3.65)$ \\
\hline _cons & $13.8769^{* * *}(-2.53)$ & $-12.8029^{* * *}(-4.55)$ & $-1.0741^{* * *}(-1.38)$ & $-8.6339^{* * *}(-1.55)$ & $-7.9281^{* * *}(-1.37)$ \\
\hline Observations & 200 & 200 & 200 & 180 & 180 \\
\hline Number of sections & 10 & 10 & 10 & 10 & 10 \\
\hline Control time & YES & YES & YES & YES & YES \\
\hline Control area & YES & YES & YES & YES & YES \\
\hline
\end{tabular}

Note. T-values are in parentheses. ${ }^{* * *}$ denotes statistical significance at $1 \%,{ }^{* *}$ denotes statistical significance at $5 \%$, and ${ }^{*}$ denotes statistical significance at $10 \%$. Since the variable FO have cover the time period 2000-2019, the time period of all variables used for basic empirical equations (1)-(3) is 2000-2019. But the newest data of variable KOFFI indicator published by Gygli et al. [33] is disclosed only until the end of 2017. So the time period of all variables used for the robustness tests (4) and (5) is 2000-2017.

3.4. Analysis of Empirical Results. From the regression results, it can be seen that the degree of investment openness can significantly affect national external wealth: Increasing the degree of investment openness is not conducive to the growth of national external wealth in the short term, but it is conducive to the growth of national external wealth in the long run. After considering the valuation effects, which is an important factor affecting changes in national external 
TABLE 4: Regression results of the instrumental variables.

\begin{tabular}{|c|c|c|c|c|c|c|c|}
\hline & $\begin{array}{c}\text { Stage } 1 \\
F O\end{array}$ & & $\begin{array}{c}\text { Stage } 2 \\
n f a\end{array}$ & & $\begin{array}{c}\text { Stage } 1 \\
F O\end{array}$ & & $\begin{array}{c}\text { Stage } 2 \\
n f a\end{array}$ \\
\hline KOFecgldj & $0.2966 *(1.82)$ & $F O$ & $\begin{array}{c}-0.3542^{*} \\
(-1.78)\end{array}$ & KOFingldj & $0.9376^{* * *}(2.77)$ & $F O$ & $\begin{array}{c}-0.1938^{*} \\
(-1.68)\end{array}$ \\
\hline$L-F O$ & $\begin{array}{l}0.8604^{* * *} \\
(21.61)\end{array}$ & $L-F O$ & $0.3041 *(1.75)$ & $L-F O$ & $0.8034^{* * *}(17.77)$ & $L-F O$ & $0.1652^{*}(1.64)$ \\
\hline$z$ & $-0.0592(-1.43)$ & $z$ & $-0.0010(-0.05)$ & $z$ & $0.0099(0.21)$ & $z$ & $0.0076(0.53)$ \\
\hline$g d p$ & $0.0372(0.85)$ & $g d p$ & $0.0207(0.98)$ & $g d p$ & $-0.0515(-0.85)$ & $g d p$ & $0.0072(0.49)$ \\
\hline$T R$ & $\begin{array}{c}-0.4068^{*} \\
(-1.97)\end{array}$ & $T R$ & $0.0500(0.50)$ & $T R$ & $-0.1972(-0.96)$ & $T R$ & $0.1034(1.39)$ \\
\hline$L 2-T R$ & $0.4335^{* *}(2.19)$ & $L-T R$ & $-0.0014(-0.01)$ & $L-T R$ & $0.3492^{*}(1.79)$ & $L-T R$ & $-0.0663(-0.85)$ \\
\hline _cons & $-1.2167^{*}(-1.77)$ & _cons & $0.0287 *(1.70)$ & _cons & $\begin{array}{c}-3.9318^{* * *} \\
(-2.75)\end{array}$ & _cons & $0.0241^{*}(1.70)$ \\
\hline Obs & 180 & Obs & 180 & Obs & 180 & Obs & 180 \\
\hline Sections & 10 & Sections & 10 & Sections & 10 & Sections & 10 \\
\hline $\begin{array}{l}\text { Control } \\
\text { period }\end{array}$ & YES & $\begin{array}{c}\text { Control } \\
\text { period }\end{array}$ & YES & $\begin{array}{l}\text { Control } \\
\text { period }\end{array}$ & YES & $\begin{array}{l}\text { Control } \\
\text { period }\end{array}$ & YES \\
\hline Control area & YES & Control area & YES & Control area & YES & Control area & YES \\
\hline
\end{tabular}

Note. T-values are in parentheses. ${ }^{* * *}$ denotes statistical significance at $1 \%,{ }^{* *}$ denotes statistical significance at $5 \%$, and ${ }^{*}$ denotes statistical significance at $10 \%$. In addition, the newest data of variable KOFecgldj and KOFingldj indicator published by Gygli et al. [33] is disclosed only until the end of 2017. So the time period of all variables used for the robustness tests (4) and (5) is 2000-2017.

wealth, we find that the significant impact of the degree of investment openness on external wealth is realized through valuation effects. Specifically, the short term decline in investment openness will produce positive valuation effects, which will drive growth of national external wealth. However, during the lag period when investment openness declines, it will have negative valuation effects, which will lead to a decrease in national external wealth.

The conclusion shows that investment openness is not conducive to growth of national external wealth at the moment, but it can promote growth of national external wealth in the long run. If the intention of the US government's policy of restricting foreign investment is to increase its own external wealth, this policy can promote an increase in external wealth to a certain extent in the short term, but from the empirical analysis results of the lag period, this policy has obvious short-sighted defects and is a false proposition under the trend of globalization.

However, this part of the empirical analysis only explains the impact of investment openness on national external wealth and has not yet revealed the dynamic transmission mechanism of investment openness to national external wealth, especially the role of valuation effects in this transmission mechanism. Therefore, the next part of this paper will use the NOEM theoretical analysis paradigm to further explore the above problems by constructing the DSGE model.

3.5. Construction and Analysis of Theoretical Models. The above empirical analysis has studied the relationship between investment openness and national external wealth in the spotand-lag period, but it still cannot explain the mechanism of investment openness on national external wealth. Therefore, we would construct the DSGE model based on the NOEM theoretical analysis paradigm in this section, and this model originated from the classical "two countries, two commodities, and two investment products" model proposed by Coeurdacier et al. [34] and Galí and Monacelli [37]. By using the DSGE models, the impacts mechanism between variables can be found out and the sustainability of the impacts can be investigated. Such as DSGE model proposed by Amiri et al. [38], the change trend of many macrovariables can be effectively observed under the shocks of oil price. Based on the classical DSGE model, we would further introduce the valuation effects and the exogenous variable standing for investment openness in the theoretical models proposed by Tille and van Wincoop [24] and Nguyen [23]. With the DSGE analysis framework, we could explore the dynamic influential mechanism of investment openness on national external wealth more clearly than the results of empirical analysis.

\subsection{Theoretical Model Description}

3.6.1. Household Utility and Consumption Function. The household utility function is as follows:

$$
\max : E_{0} \sum_{t=0}^{\infty} \beta^{t}\left(\frac{1}{1-\sigma} C_{H, t}{ }^{1-\sigma}-\frac{1}{1+\omega} L_{H, t}^{1+\omega}\right)
$$

where subscript $H$ represents the home country and $F$ represents the foreign country. $\beta$ represents the discount factor. ${ }_{C}^{H, t}$ represents domestic consumption in period $t . L_{H, t}$ represents labor effort, $\sigma$ is the coefficient of risk aversion and greater than 1 , and $\omega$ represents elasticity of labor supply and greater than 0 .

The consumption function is

$$
C_{H, t}=\left[a^{1 / \phi}\left(c_{H, t}^{H}\right)^{(\phi-1) / \phi}+(1-a)^{1 / \phi}\left(c_{F, t}^{H}\right)^{(\phi-1) / \phi}\right]^{\phi /(\phi-1)},
$$

where $c(H / F, t)$ represents the home country's consumption of goods produced by the foreign country in period $t, a$ 
represents the preference of consuming domestic products, $0.5<a<1$, and $\phi$ represents the elasticity of substitution between domestic and foreign products.

Assuming that purchasing power parity holds, based on the above preferences, the consumer price index $P_{H, t}$ can be theorized as follows:

$$
P_{H, t}=\left[a\left(p_{H, t}\right)^{1-\phi}+(1-a)\left(e_{t} p_{F, t}^{*}\right)^{1-\phi}\right]^{1 /(1-\phi)},
$$

$p_{H, t}$ represents the unit price of domestic product, $p_{F, t}^{*}$ represents the unit price of foreign product, $e_{t}$ represents the nominal exchange rate, and equations $P_{F, t}=e_{t} P_{F, t}^{*}$ and $P_{F, t}=e_{t} P_{F, t}^{*}$ hold. Therefore, the relationship between domestic and foreign products and the consumption index can be described as follows:

$$
\begin{aligned}
c_{H, t}^{H} & =a\left(\frac{p_{H, t}}{P_{H, t}}\right)^{-\phi} C_{H, t}, \quad c_{F, t}^{H} \\
& =(1-a)\left(\frac{e_{t} p_{F, t}^{*}}{P_{H, t}}\right)^{-\phi} C_{H, t} .
\end{aligned}
$$

Since purchasing power parity holds, the relationship between the price in local currency and the price in foreign currency can be expressed as

$$
\begin{gathered}
p_{F, t}=e_{t} p_{F, t}^{*}, \\
P_{F, t}=e_{t} P_{F, t}^{*}, \\
p_{H, t}^{*}=\frac{p_{H, t}}{e_{t}}, \\
P_{H, t}^{*}=\frac{P_{H, t}}{e_{t}},
\end{gathered}
$$

where $p_{F, t}$ and $P_{F, t}$ are the foreign product price and foreign product price index in the local currency, respectively, and $p_{H, t}^{*}$ and $P_{H, t}^{*}$ are the domestic product price and domestic product price index in foreign currency, respectively.

3.7. Technologies and Manufacturers Functions. The production function, technological impact, and capital dynamics can be expressed as

$$
\begin{aligned}
Y_{H, t} & =z_{H, t}\left(K_{H, t}\right)^{\kappa}\left(L_{H, t}\right)^{1-\kappa}, \\
K_{H, t+1} & =(1-\delta) K_{H, t}+\chi_{H, t} I_{H, t}, \\
\ln \left(z_{H, t}\right) & =\rho_{H z} \ln \left(z_{H, t-1}\right)+\varepsilon_{H z, t}, \\
\ln \left(\chi_{H, t}\right) & =\rho_{H \chi} \ln \left(\chi_{H, t-1}\right)+\varepsilon_{H \chi, t},
\end{aligned}
$$

$Y_{H, t}$ represents domestic output in period $t . z_{H, t}$ is an exogenous random variable total factor productivity (TFP) and in accordance with the AR (1) process. $K_{H, t}$ represents the domestic stock of the capital. $\kappa$ represents the elasticity of capital output, $1-\kappa$ represents the elasticity of labor output, and $0<\kappa<1 . \delta$ represents the constant depreciation rate of capital. $\chi_{H, t}>0$ and is an exogenous random shock to investment efficiency, which is also in accordance with the AR (1) process.

Gross investment is generated using domestic and foreign inputs; the investment function is

$$
I_{H, t}=\left[a^{1 / \phi}\left(i_{H, t}^{H}\right)^{(\phi-1) / \phi}+(1-a)^{1 / \phi}\left(i_{F, t}^{H}\right)^{(\phi-1) / \phi}\right]^{\phi /(\phi-1)},
$$

where $I_{H, t}$ is the gross investment in home country at date $t$. $i_{H, t}^{H}$ and $i_{F, t}^{H}$ express the amount of domestic investment in domestic investment products and foreign investment products, respectively. According to the classical research model about national external wealth proposed by Coeurdacier et al. [34], we assume investment preference and substitution elasticity parameters are consistent with the consumption function for simplifying the calculation of logarithmic linearity of the model, and the price of investment products would be also consistent with that of consumer products. Therefore, the domestic investment products can be expressed as

$$
\begin{aligned}
i_{H, t}^{H} & =a\left(\frac{p_{H, t}}{p_{H, t}}\right)^{-\phi} I_{H, t}, \quad i_{F, t}^{H} \\
& =(1-a)\left(\frac{e_{t} p_{F, t}^{*}}{p_{H, t}}\right)^{-\phi} I_{H, t} .
\end{aligned}
$$

Assuming that the residual profits of the manufacturers after paying wages, costs, and investment are all used to pay dividends, the expressions of wage expenditure $\left(w_{H, t} L_{H_{t}}\right)$, dividend $\left(D_{H, t}\right)$, and capital optimization in equilibrium are as follows:

$$
\begin{aligned}
w_{H, t} L_{H, t}= & p_{H, t}(1-\kappa) z_{H, t}\left(K_{H, t}\right)^{\kappa}\left(L_{H, t}\right)^{1-\kappa} \\
= & (1-\kappa) p_{H, t} Y_{H, t}, \\
D_{H, t}= & \kappa p_{H, t} Y_{H, t}-P_{H, t} I_{H, t}, \\
1= & E_{t} \beta\left(\frac{C_{H, t+1}}{C_{H, t}}\right)^{-\sigma}\left(\frac{\chi_{H, t}}{P_{H, t+1}}\right) \\
& \cdot\left[\kappa p_{H, t+1} \frac{Y_{H, t+1}}{K_{H, t+1}}+(1-\delta) \frac{P_{H, t+1}}{\chi_{H, t+1}}\right] .
\end{aligned}
$$

3.7.1. Household Constraints, Capital Markets, and Market Clearing. In terms of the degree of investment openness, we introduce the classical exogenous variable $\tau$ standing for the investment barrier factors and have been widely described in the DSGE model by Tille and van Wincoop [24], Pavlova et al. [14], and Nguyen [23]. This variable could represent the hurdles of investing abroad and the expenses spent to overcome cultural and language barriers, as well as the degree of investment openness. When $\tau>0,0<e^{-\tau}<1$, the larger the $\tau$, the higher the barriers to mutual investment, the greater the loss of cross-border investment, and the lower 
the attractiveness of foreign assets, and the lower the degree of investment openness. Thus the variable FO mentioned in empirical research of Section 3 could be replaced by $\tau$ in the DSGE model research of this section. $1-e^{-\tau}$ represents the income received by a country due to the establishment of investment barriers, which reflects the cost of foreign investment to enter the domestic market. The home country household budget constraint equation is

$$
\begin{aligned}
& P_{H, t} C_{H, t}+s_{H, t+1}^{H} Q_{H, t}+s_{F, t+1}^{H} Q_{F, t} \\
& =w_{H, t} L_{H, t}+s_{H, t}^{H}\left(Q_{H, t}+D_{H . t}\right)+s_{F, t}^{H}\left(Q_{F, t}+D_{F, t}\right) e^{-\tau} \\
& \quad+s_{H, t}^{F}\left(Q_{H, t}+D_{H, t}\right)\left(1-e^{-\tau}\right),
\end{aligned}
$$

where $s_{F}^{H}$ is the domestic share of foreign assets and $s_{H}^{F}$ is the foreign share of domestic assets. $Q_{H}$ is the value of domestic assets, and $Q_{F}$ is the value of foreign assets. Equation (13) means each household selects investment, consumptions, and labor supplies that maximize their life-time utility (4) subject to their budget constraint (18) for $t \geq 0$. Therefore, the family Euler equations are as follows:

$$
\begin{aligned}
C_{H, t}^{-\sigma} & =\beta E_{t}\left[C_{H, t+1}^{-\sigma}\left(\frac{P_{H, t}}{P_{H, t+1}}\right)\left(\frac{Q_{H, t+1}+D_{H, t+1}}{Q_{H, t}}\right)\right] e^{-\tau}, \\
E_{t}\left(\frac{Q_{H, t+1}+D_{H, t+1}}{Q_{H, t}}\right) & =E_{t}\left(\frac{Q_{F, t+1}+D_{F, t+1}}{Q_{F, t}}\right), \\
L_{H, t}{ }^{\omega} & =\frac{w_{H, t} C_{H, t}^{-\sigma}}{P_{H, t}} .
\end{aligned}
$$

The clearing of product market and capital market is described as follows:

$$
\begin{gathered}
c_{H, t}^{H}+c_{H, t}^{F}+i_{H, t}^{H}+i_{H, t}^{F}=Y_{H, t}, \\
c_{F, t}^{F}+c_{F, t}^{H}+i_{F, t}^{F}+i_{F, t}^{H}=Y_{F, t}, \\
s_{H, t}^{H}=1-s_{H, t}^{F}: s_{F, t}^{F}=1-s_{F, t}^{H} .
\end{gathered}
$$

3.7.2. Constituents of Changes in National External Wealth. After describing the macroeconomic operation system, the relationship between the valuation effects $\left(\mathrm{VA}_{H, t}\right)$ represents changes of the stock value about national external wealth, and the current account $\left(\mathrm{CA}_{H, t}\right)$ represents changes of the flow value about national external wealth. So national external wealth $\left(\mathrm{NFA}_{H, t}\right)$ could be described as follows, according to the relationship described by Devereux and Sutherland [28]:

$$
\begin{aligned}
\Delta \mathrm{NFA}_{H, t+1}= & \mathrm{VA}_{H, t}+\mathrm{CA}_{H, t}, \\
\mathrm{VA}_{H, t}= & s_{F, t+1}^{H}\left(Q_{F, t+1}-Q_{F, t}\right) \\
& -s_{H, t+1}^{F}\left(Q_{H, t+1}-Q_{H, t}\right) \\
& -s_{F, t}^{H} Q_{F, t}\left(1-e^{-\tau}\right)+s_{H, t}^{F} Q_{H, t}\left(1-e^{-\tau}\right) .
\end{aligned}
$$

Equation (17) is the expression of valuation effects taking the factor of investment openness into consideration under the direct method, which is reflected by deducting the change of market value of home assets held by foreign countries from the change of market value of foreign assets held by home country. This equation indicates that, due to the existence of the transnational investment barrier factor $\tau$, the value of the home country's outbound investment is lost $\left(1-e^{-\tau}\right)$. Meanwhile, the current account is not affected by cross-border investment barriers. We further subdivide it into the trade balance $(T B)$ caused by international trade and the income balance $(I B)$ caused by gains and losses on international investment, where IB can be expressed as

$$
\mathrm{IB}_{H, t}=s_{F, t}^{H} D_{F, t}-s_{H, t}^{F} D_{H, t} .
$$

Equation (18) is the expression of income balance, which is reflected by deducting the income obtained on the home assets held by foreign countries from the income obtained on foreign assets held by the home country. According to the DSGE model analysis framework, linearization is carried out in the neighborhood of the steady state to reflect the dynamic response of each variable in response to the impact. This study investigates the changes in external macroeconomic equilibrium, and the values of variables NFA, VA, $\mathrm{CA}, \mathrm{TB}$, and IB that reflect external macroeconomic equilibrium are all relative values that reflect the differences between home and abroad. Therefore, all variables in this study are expressed as the difference between domestic and foreign variables after the linear expansion. ${ }^{5}$ Then we can acquire eighteen linear equations of production, price, capital dynamics, equilibrium manufacturer's wage expenditure, dividends, capital and budget constraints, Euler equation, the dynamic equation of market clearing, and the 
above external economic variables from equations (20)-(36). All of these equations are expressed as follows and would be available for numerical simulation of DSGE model to explore the dynamic influence mechanism between variables:

$$
\begin{aligned}
& \hat{Y_{t}^{d}}=\kappa \hat{K_{t}^{d}}+(1-\kappa) \hat{L_{t}^{d}}+\hat{z_{t}^{d}} \\
& \hat{p_{t}^{d}}=(2 a-1) \hat{p_{t}^{d}} \\
& \stackrel{\wedge}{K_{t+1}^{d}}=(1-\delta) \hat{K_{t}^{d}}+\delta\left(\hat{\chi_{t}^{d}}+\hat{I_{t}^{d}}\right) \\
& \hat{W_{t}^{d}}+\hat{L_{t}^{d}}=\hat{Y_{t}^{d}}+\hat{p_{t}^{d}} \\
& \hat{D D_{t}^{d}}=\kappa p Y\left(\hat{p_{t}^{d}}+\hat{Y_{t}^{d}}\right)-\operatorname{PI}\left(\hat{p_{t}^{d}}+\hat{I_{t}^{d}}\right)
\end{aligned}
$$

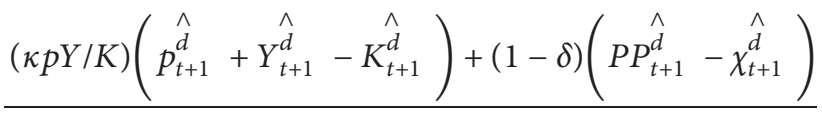

$$
\begin{aligned}
& (\kappa p Y / K)+(1-\delta) P \\
& =\sigma \hat{C}_{t+1}^{d}-\sigma \hat{C}_{t}^{d}+P_{t+1}^{\hat{d}}-\hat{\chi_{t}^{d}}, \\
& P C\left(\hat{p_{t}^{d}}+\hat{C_{t}^{d}}\right)+s Q s_{t+1}^{+H F}+(1-s) Q s_{t+1}^{-\hat{H F}}=\left(\hat{W}_{t}^{d}+\hat{L_{t}^{d}}\right) w L+s Q s_{t}^{+H F} \\
& +s D\left(s_{t}^{+H F}+\hat{D}_{t}^{d}\right)+(1-s) Q\left(2 \hat{Q}_{t}^{d}-\hat{s}_{t}^{-H F}\right)+(1-s) D\left(\hat{D}_{t}^{d}-s_{t}^{-H F}\right) \\
& +2 e^{-\tau}(1-s) Q\left(s_{t}^{\wedge}-\hat{Q_{t}^{d}}\right)+2 e^{-\tau}(1-s) D\left(s_{t}^{-H F}-\hat{D}_{t}^{d}\right), \\
& \hat{Q_{t}^{d}}=\frac{Q_{Q_{t+1}^{d}}^{\wedge} \hat{D}_{t+1}^{\hat{d}}}{Q+D} \\
& -\sigma \hat{C}_{t}^{d}=\hat{p_{t}^{d}} \\
& \hat{W_{t}^{d}}-\hat{p_{t}^{d}}=\hat{\wedge} \hat{L}_{t}^{d}+\sigma \hat{C}_{t}^{d}, \\
& (C+I) \phi\left[(2 a-1) \hat{p_{t}^{d}}-\hat{p_{t}^{d}}\right]+(2 a-1)\left(\hat{C C_{t}^{d}}+\hat{I I}_{t}^{d}\right)=\hat{Y} \hat{Y}_{t}^{d} \\
& s s_{t}^{+H F}=(1-s) s_{t}^{-H F} \\
& \hat{z_{t}^{d}}=\rho_{z} z_{t-1}^{\hat{d}}+\varepsilon_{H F z, t}, \quad \hat{\chi_{t}^{d}} \\
& =\rho_{\chi} \chi_{t-1}^{\hat{d}}+\varepsilon_{H F \chi, t},
\end{aligned}
$$




$$
\begin{aligned}
\hat{N F A}_{H, t} & =\frac{(1-s) Q}{Y}\left(s_{t}^{-H F}-\hat{Q}_{t}^{d}\right) \\
V \hat{A}_{H, t} & =\frac{(1-s) Q}{Y}\left[\left(2-e^{-\tau}\right) \hat{Q}_{t}^{d}-\hat{Q}_{t+1}^{d}-\left(1-e^{-\tau}\right) s_{t}^{-H F}\right] \\
\hat{I B}_{H, t} & =\frac{(1-s) D e^{-\tau}}{Y}\left(\hat{s}_{t+1}^{-H F}-\hat{D}_{t}^{d}\right) \\
\hat{C A}_{H, t} & =\mathrm{NFA}_{H, t+1}-\mathrm{NFA}_{H, t}-\hat{\mathrm{VA}}_{H, t}, \\
\hat{\mathrm{TB}}_{H, t} & =\hat{\mathrm{CA}}_{H, t}-\mathrm{IB}_{H, t} \cdot
\end{aligned}
$$

\section{Numerical Simulation Analysis}

4.1. Calibration. In order to analyze the above theory better, we set the value of eight exogenous parameters in Table 5 (the static parameters are determined by the calibration method and the corresponding dynamic parameters are determined by estimation). And the parameters in Table 5 are calibrated to the annual value. Because the model proposed above is based on the research model of Coeurdacier et al. [34] and Ghironi et al. [22], the calibration value of the main eight parameters in Table 5 would refer to their research.

The parameter persistence of technological innovation shocks $\rho_{z}$ and the corresponding random impact parameter $\varepsilon_{z}$ in the impact equation are estimated using generalized method of moments (GMM) estimation. In terms of the estimated value, the value of technology innovation impact $\left(\ln z_{t}\right)$ and investment efficiency impact $\left(\ln \chi_{t}\right)$ in 2000-2019 are constituted with data of the major economies, including the US, Japan, the Euro area, the UK, Canada, Australia, China, India, Brazil, and Russia. The estimated results are shown in Table 6.

4.1.1. Numerical Simulation Analysis under Technological Innovation Impact. Numerical simulation analysis of the impact of technological innovation was carried out by setting different $\tau$ values to reflect the different degrees of investment barriers in the economic environment and then further reflect the different degrees of investment openness. Dynamic simulation is carried out to characterize and analyze the impact of investment openness on valuation effects and current account, and then the dynamic adjustment effect on external wealth can be analyzed. According to the classical DSGE model proposed in the research of Nugyen [23], the exogenous variable $\tau$ has been set to be 0.10 , represented for a suitable position of the investment openness. So we assume $\tau=0.01,0.10$, and 0.20 and represent the degree of investment openness of high, medium, and low, respectively. The impulse responses under $1 \%$ technology impact are showed in Figure 1; it can be seen from the impulse response results in Figure 1.
(1) As the degree of investment openness decreases, the share of outward investment $(S F)$ shows a downward trend. This is mainly due to the investment barriers that increase the cost of international investment, which lowers the attractiveness of domestic assets to foreign investment.

(2) The asset price difference $(Q)$ between domestic and foreign countries first decreases and then increases rapidly with the decrease in investment openness. The initial decline in asset prices as investment barriers increased was mainly due to increased barriers and restrictions on cross-border investment at the beginning, which made it less attractive for both domestic and foreign residents to invest abroad. In the early stages of the impact, however, the income of domestic residents is relatively higher than that of foreign residents, which means that the capacity of domestic residents to invest in foreign assets is greater than that of foreign residents to invest in domestic assets. Therefore, domestic residents have a relatively high demand for foreign assets, which makes the prices of foreign assets rise while the prices of domestic assets fall relatively. As the impact continues, domestic technological innovation improves the profitability of domestic assets, resulting in excess returns on domestic assets compared with foreign assets. Foreign capital is more willing to invest in domestic assets and pay the costs of entry, and the higher the investment barrier is, the higher the entry costs will be, and the more "ticket income" the domestic residents will receive. At the same time, in order to avoid the loss caused by the limitation of cross-border investment, domestic residents are more willing to invest the new income in domestic assets. Therefore, during the duration of the impact, the investment attractiveness of domestic assets continues to increase, which leads to the continuous rise of domestic asset prices.

(3) The current account $(C A)$, representing changes of the flow value about national external wealth, shows a worsening trend with the reduction of investment 
TABLE 5: Calibrated static parameters.

\begin{tabular}{lcccc}
\hline Variable & Variable definitions & Value & Variable & Variable definitions \\
\hline$\beta$ & The discount factor & 0.99 & $\sigma$ & Consumer risk aversion coefficient 2.00 \\
$\delta$ & Capital depreciation rate & 0.10 & $\kappa$ & Capital as a proportion of production \\
$a$ & Home country consumption/investment preference & 0.85 & $\omega$ & Elasticity of labor supply \\
$\phi$ & Elasticity of substitution between domestic and foreign & 3.50 & $P$ & Steady-state price index \\
\hline
\end{tabular}

TABle 6: Estimated dynamic parameters.

\begin{tabular}{|c|c|c|c|c|c|}
\hline $\mathrm{a}$ & $\mathrm{V}$ & e & $\mathrm{Va}$ & Variable definitions & $\mathrm{V}$ \\
\hline & $\begin{array}{c}\begin{array}{c}\text { Persistence of technological innovation } \\
\text { shocks }\end{array}\end{array}$ & & & $\begin{array}{r}\text { Standard error of random tec } \\
\text { shocks }\end{array}$ & \\
\hline$\theta^{\prime}$ & Persistence of investment efficiency shocks & 0.9358 & $S E$ & Standard error of random investment efficiency shocks & 0.0402 \\
\hline
\end{tabular}

Note. The above technological innovation impact and investment efficiency impact parameters are significant at $1 \%$.

openness, thus having an adverse impact on national external wealth. By subdividing the current account into trade balance $(T B)$, which represents the flow of wealth due to international trade and income balance $(I B)$, which represents the flow of wealth due to investment returns, we conducted further analysis. According to the expression of equations (20)-(22), (25), (29), and (30), variables such as domestic output, consumption, investment, and product prices are not affected by investment barriers, so international trade is not affected by the degree of investment openness. However, based on the linear expression of income balance reflected in equation (35), it can be seen that the share of outward investment $(S F)$ will decrease with the deepening of international investment restrictions, which will lead to a decline in income balance (IB) performance, resulting in the deterioration of the whole current account. Therefore, the decline in investment openness will ultimately lead to a decrease of the flow value about national external wealth, and the flow change comes from investment income rather than international trade.

(4) With the decrease in investment openness, the valuation effects $(V A)$ representing changes of the stock value about national external wealth would be improved in the short term and thus have a favorable influence on national external wealth. It can be seen from the linear equation of the valuation effects in equation (34) that the valuation effects are influenced by both the asset price $\left(\left(1-e^{-\tau}\right) Q_{t}^{d}\right)$ and the dynamic outward investment share $\left(\left(1-e^{-\tau}\right) s_{t}^{-H F}\right)$. With the increase in investment barriers, the outward investment share $\left(s_{t}^{-H F}\right)$ decreases while $\left(1-e^{-\tau}\right)$ increases, so it cannot be determined whether the outward investment share is the reason for improving the valuation effects. However, as investment barriers increase, asset prices $\left(Q_{t}^{d}\right)$ will first fall and then rise, while $\left(1-e^{-\tau}\right)$ will rise, further improving the valuation effects. Combined with the numerical simulation in Figure 1, it can be deduced that the improvement of the valuation effects with the increase in investment barriers is mainly due to the positive dynamics impact of asset prices. From an economic perspective, foreign capital is more willing to invest in domestic assets due to excess returns, so capital continues to flow inwards. With the increase in investment barriers, the entry costs for foreign capital are increasing, and the income $\left(Q_{H, t}\left(1-e^{-\tau}\right)\right)$ domestic residents received from entry costs is therefore increasing, which eventually leads to the stock improvement of the external wealth of domestic nation.

(5) NFA representing national external wealth would be improved in the short term ( $0-5$ periods) as the degree of investment openness declines but deteriorate in the long term (5-50 periods). This shows that in the short term the decline in investment openness drives the overall improvement of national external wealth through valuation effects. However, this improvement is not sustainable. In the long run, as investment barriers restrict international capital flow, the decline of external investment income (IB) in the current account $(C A)$ will reduce the inflow of national external wealth and eventually lead to the deterioration of national external wealth.

4.1.2. Numerical Simulation Analysis under Investment Efficiency Impact. Similar to the above analysis of the impact of technological innovation that represents business cycle impact, this paper represents the financial cycle impact with investment efficiency improvement impact [39] and studies the dynamic changes of each variable after the $1 \%$ investment efficiency improvement impact in different levels of international investment openness (reflected by $\tau$ ). Similar to the shock of technology innovation, the shock of investment efficiency improvement will improve domestic production efficiency of home country and increase domestic output. And with the growth of domestic output, various variables under the open economic system designed by us would interact with each other dynamically. 

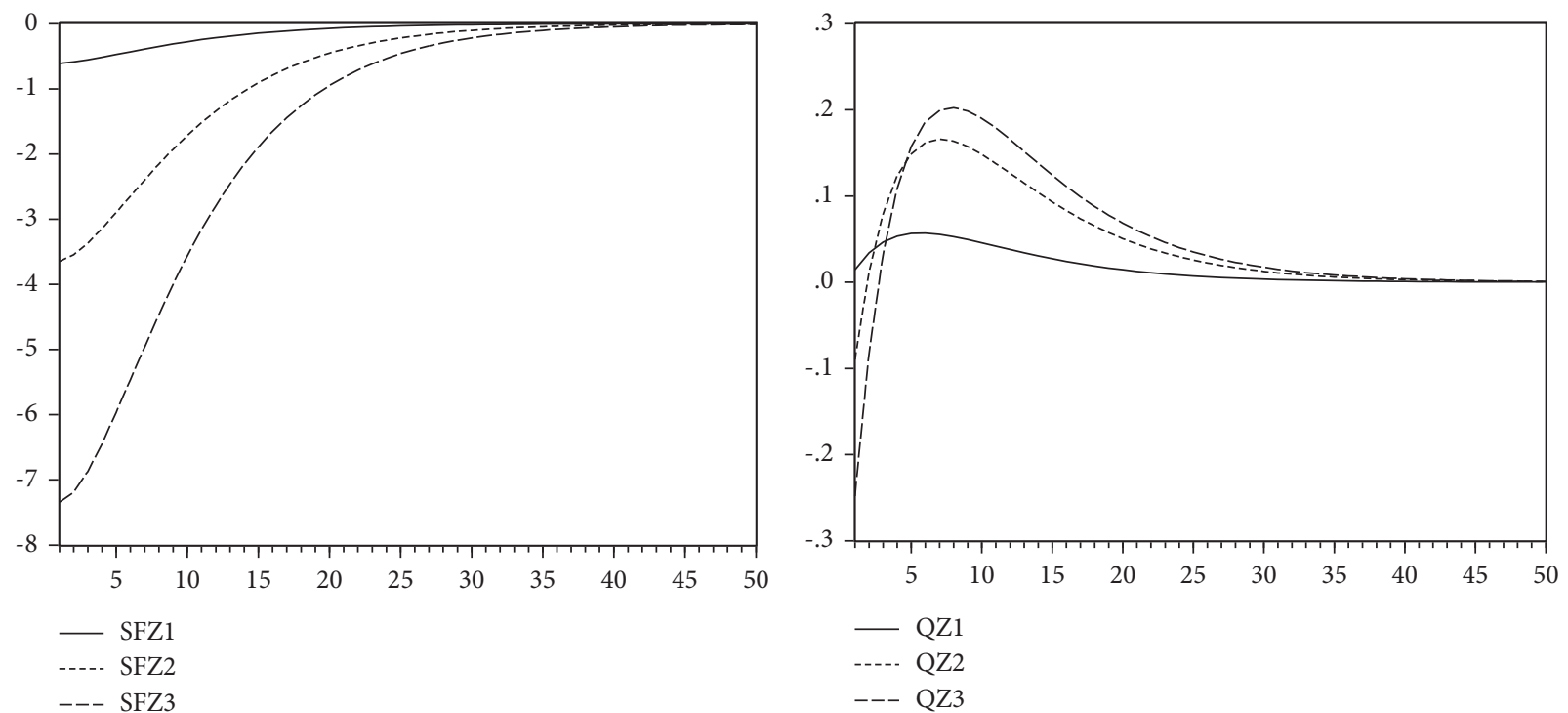

(a)

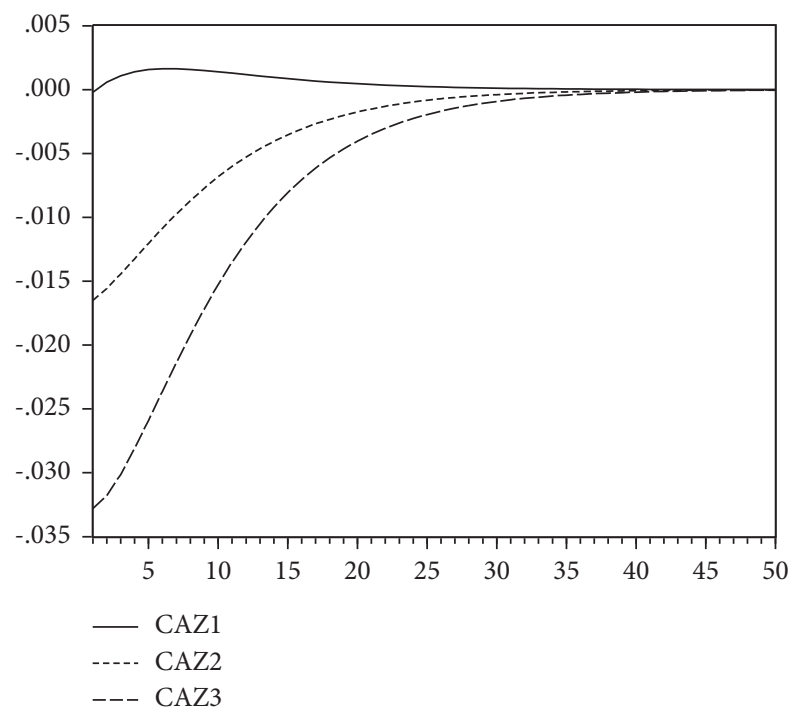

(b)

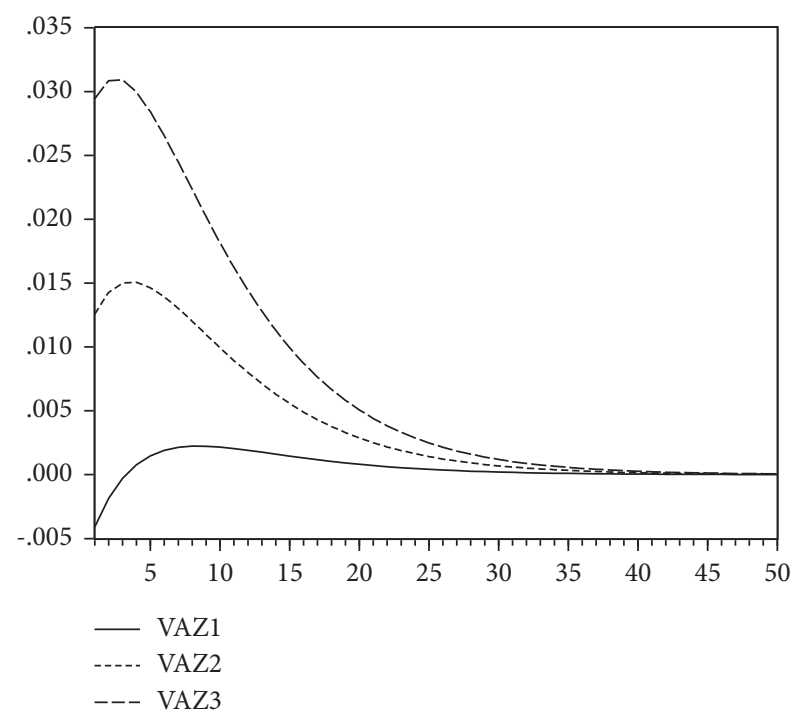

(c)

(d)

Figure 1: Continued. 


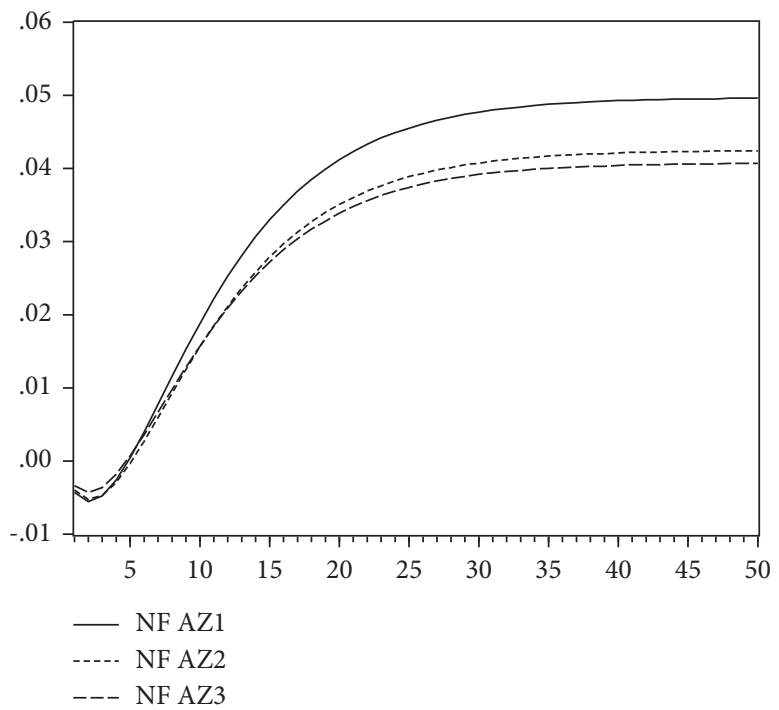

(e)

Figure 1: Technological innovation shock (1\%), the dynamic response of variables under different degrees of investment openness. Note: 1. The solid line, the short dotted line, and the long dotted line represent the $\tau$ value at $0.01,0.10$, and 0.20 , respectively. Note: 2 . SF represents the share of outward investment, $Q$ represents the asset price difference, CA represents current account, VA represents the valuation effects, and NFA represents national external wealth. SFZ represents the impulse response route of SF after being impacted by technology innovation (Z); then SFZ1, SFZ2, and SFZ3 represent the dynamic trend of the share of outward investment impacted by technology innovation when the $\tau$ value is at $0.01,0.10$, and 0.20 , respectively. $Q, C A, V A$, and NFA express the same meaning as SF.

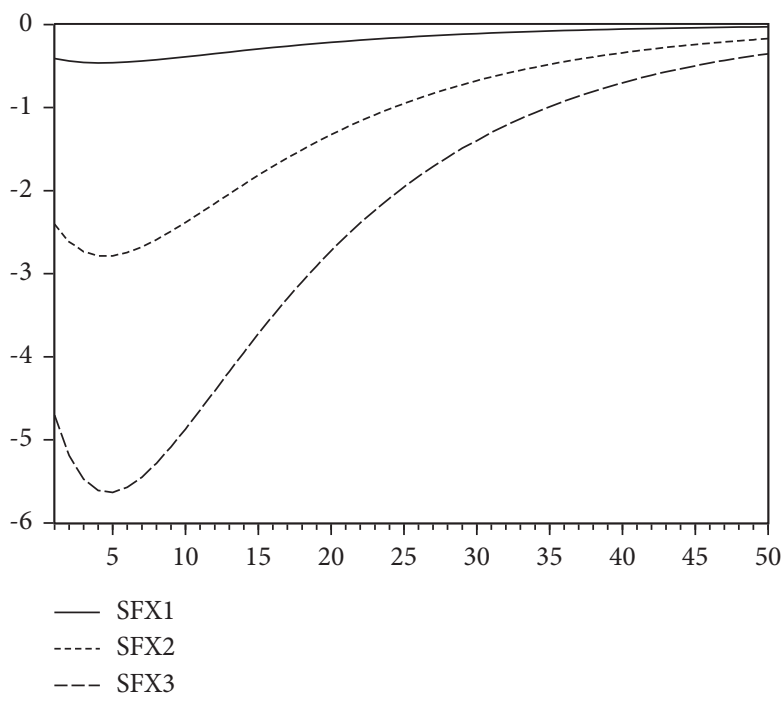

(a)

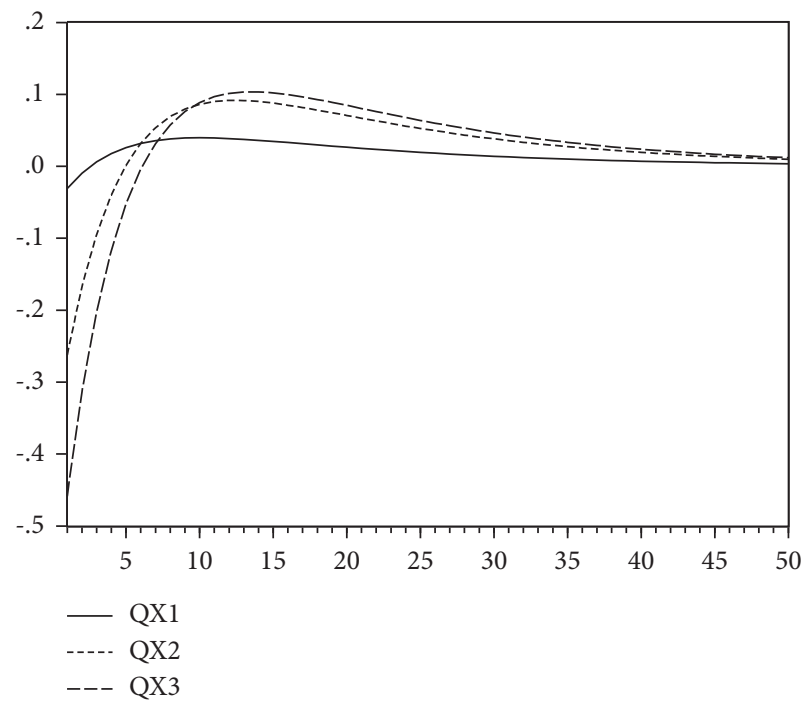

(b)

FIgUre 2: Continued. 


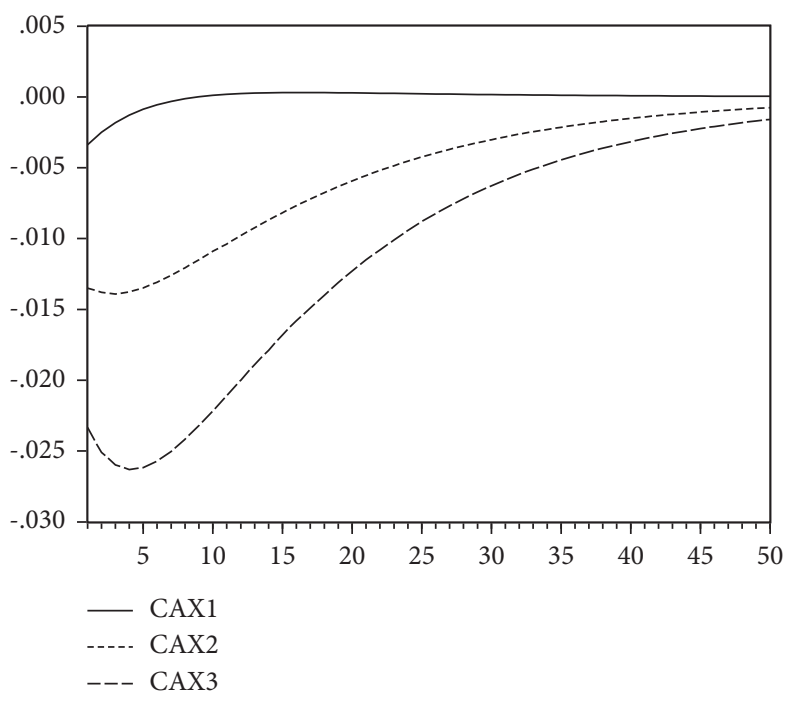

(c)

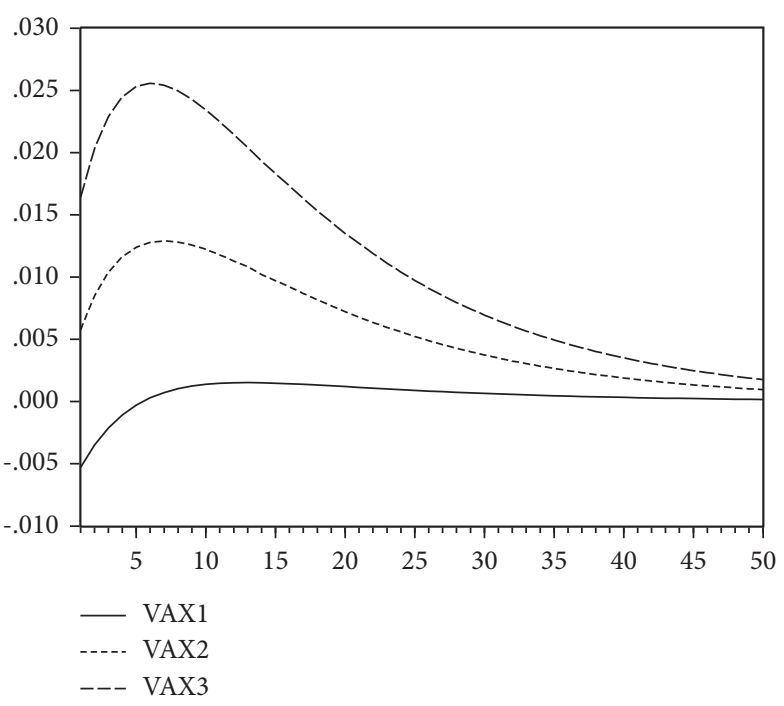

(d)

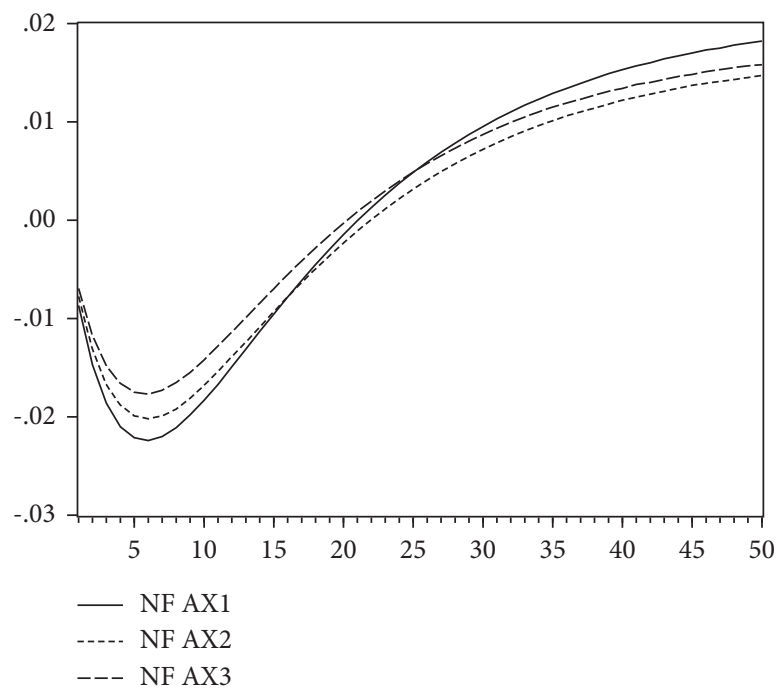

(e)

Figure 2: Investment efficiency improvement shock (1\%), the dynamic response of variables under different degrees of investment openness. Note: The solid line, the short dotted line, and the long dotted line represent the $\tau$ value at $0.01,0.10$, and 0.20 , respectively. SFX represents the impulse response route of SF after being impacted by investment efficiency improvement (X), then SFX1, SFX2, and SFX3 represent the dynamic trend of the share of outward investment impacted by investment efficiency improvement when the $\tau$ value is at 0.01 , 0.10 , and 0.20 , respectively. Q, CA, VA, and NFA express the same meaning as SF.

As can be seen from the impulse response in Figure 2, with the deepening of investment openness, the dynamic trend of variables $s_{t}^{-H F}$ and $Q_{t}^{d}$ under the impact of investment efficiency improvement are similar to those under the impact of technological innovation. At the same time, the dynamic adjustment trajectories of current account, valuation effects, and national external wealth are similar to those of technological innovation shock.

Comparing Figure 2 with Figure 1, we could acquire the differences between the impulse responses of variables caused by two kinds of shocks. Under the higher investment openness $(\tau=0.01)$, the external wealth of home country originated from investment efficiency improvement on the long run would by lower than the external wealth of home country originated from technological innovation. This indicates that the shock of investment efficiency improvement would have a lower impact on national external wealth than the shock of technological innovation.

Based on the above DSGE research, the dynamic adjustment mechanism of investment openness on national external wealth was found out. Under the impact of technological innovation and investment efficiency improvement, the decline in international investment openness will improve valuation effects and thus improve national external wealth. 
However, the improvement effect is of limited sustainability. The decrease in the degree of investment openness will lead to an increase in transnational investment barriers and an increase in investment costs, which will lead to a decrease in transnational investment income. Finally, it will not only offset the improvement of national external wealth caused by valuation effects in the short term but will also further deteriorate the external wealth in the long term. From the analysis of the above DSGE theoretical model, it can be seen that the improvement effect of investment barriers on national external wealth only works in the short term. In the long run, the decline of investment openness and the "antiglobalization" trend of international investment will eventually worsen the external wealth of domestic nation.

The differences between the DSGE analysis carried out above and previous studies are the valuation effects introduced to the model, so the technology shock and investment efficiency shock can affect national external wealth through financial adjustment channels and trade adjustment channels. Then we can investigate the internal influence mechanism of variables in DSGE model system under the two types of channels. Due to the integrity of the model, the model designed above could be also used to investigate the problems related to external imbalances between great nations.

\section{Conclusion}

Since 2018, the degree of international investment openness has been declining, which has had a series of adverse effects on economic globalization. The US government's intention to optimize its external wealth by putting up investment barriers has caused trouble for the global investment field and has hindered some economies' integration into the world economy. In contrast to trade openness, existing research has not yet reached a consensus on the impact of investment openness on various macroeconomic variables, and research on the degree of impact, sustainability, and impact mechanism is still insufficient. In addition, existing research on national external wealth does not consider the valuation effects, which makes it inadequate. Based on the above problems, this study innovatively introduces the valuation effects and uses the NOEM theoretical analysis paradigm to study the dynamic impact of investment openness on national external wealth and its impact mechanism.

This study constructs panel data from major economies of the world. Through empirical analysis, it is shown that the decline in investment openness has a positive effect on national external wealth in the short term but has a significant negative impact on national external wealth in the lag period. Considering the valuation effects, this study further uses the NOEM theoretical analysis paradigm to construct a DSGE analysis model and numerically simulates the model based on the impact of technological innovation and investment efficiency improvement. The study finds that the decline in investment openness can improve national external wealth through valuation effects in the short term. However, this effect has weak sustainability. With the decrease in cross-border investment and international investment income, the new flow value about national external wealth will continue to decline, which will eventually deteriorate national external wealth in the long run.

The conclusion of this paper has the following implications for economies committed to international investment.

First, economic globalization is an inevitable trend of global economic development, and the antiglobalization of investment will ultimately worsen national external wealth. The increase in investment barriers will inevitably lead to a decline in investment openness. Although it can improve the external wealth in the short term, due to the dynamic adjustment mechanism of investment openness to external wealth, a lower level of investment openness will eventually worsen external wealth in the long run. Therefore, in the process of building a high-quality open economy, countries should further reform and open up, gradually optimize the negative list of foreign investments, moderately open the financial market, and increase the degree of investment openness.

Second, when formulating international economic and trade policies, the valuation effects should be taken into account. Valuation effects have a significant impact on the stock value of national external wealth and are an important factor to be considered when analyzing the external economy. This is precisely because of the existence of the valuation effects that the decline in investment openness can promote national external wealth in the short term. Therefore, considering the impact of valuation effects when designing relevant international economic and trade policies will help enrich the application scope of policies and enhance the effectiveness of policy implementation.

Third, lowering barriers to international investment should focus on reducing the information asymmetry between investors and investees. The international investment scale of some emerging market countries is expanding annually. However, the host countries are quite different from home countries in terms of geopolitics, investment culture, and financial environment. To eliminate information asymmetry and reduce investment barriers, it is necessary to promote mutual understanding between investors, build an investment information exchange platform, and strengthen the government's guidance on overseas investment by enterprises for home countries. In addition, optimizing multilateral investment portfolios can effectively reduce investment barriers caused by information asymmetry.

Fourth, countries committed to international investment should strengthen the communication mechanism among major countries, establish cooperative relationships of mutual trust and mutual benefit, negotiate for reduction of investment protectionism, and work to build an optimized international investment environment. The above empirical results show that although the decline in the degree of openness caused by investment protectionism will boost national external wealth in the short term, this is a shortsighted behavior. In the long run, both sides of national external wealth will eventually deteriorate, resulting in a "lose-lose" situation. Therefore, to avoid the long term adverse effects of increasing international investment 
barriers on both sides of national external wealth, countries on Earth should establish partnerships of mutual trust and mutual benefit and work together to reduce investment protectionism and promote economic globalization.

\section{Data Availability}

The data used to support the findings of this study are available from the corresponding author upon request.

\section{Conflicts of Interest}

The authors declare that there are no conflicts of interest regarding the publication of this paper.

\section{Acknowledgments}

This research was supported by the National Social Science Foundation of China (Grant no. 19FJY042) and National Natural Science Foundation of China (Grant no. 71902035).

\section{References}

[1] H. Huang, "International investment and relationship between major countries-a comparative study on investment friction between Japan and the us and investment friction between China and the us," Forum of World Economics \& Politics, vol. 5, pp. 21-27, 2009.

[2] L. Xiong, H. Zhang, Y. Li, and Z. Liu, "Improved stability and Ho performance for neutral systems with uncertain markovian jump," Nonlinear Analysis: Hybrid Systems, vol. 19, pp. 13-25, 2016.

[3] P. O. Gourinchas and H. Rey, "Chapter 10 - external adjustment, global imbalances, valuation effects," In Handbook of International Economics, Elsevier, Amsterdam, The Netherlands, 2014.

[4] L. He, "Valuation effect and currency mismatch redefinition: a new macroeconomic application of the concept of exchange rate risk," Studies of International Finance, vol. 9, pp. 86-96, 2015.

[5] K. Liu and Q. Guo, "Valuation effects and structure of foreign equity assets: a study based on noem analysis framework," Word Economy Studies, vol. 1, pp. 54-82, 2020.

[6] M. Zhang, "A comprehensive perspective of China's foreign exchange reserve decline: valuation effect," Moderate Scale and Asset Structure, vol. 7, pp. 97-102, 2018.

[7] X. Fan, L. Xiao, and S. Fang, "From trade adjustment channel to financial adjustment channel -- the new development of international financial external adjustment theory," Journal of Financial Research, vol. 2, pp. 194-206, 2011.

[8] P. R. Lane, "International financial flows in low-income countries," Pacific Economic Review, vol. 20, no. 1, pp. 49-72, 2015.

[9] L. Liu and S. Liu, "Integrated production and distribution problem of perishable products with a minimum total order weighted delivery time," Mathematics, vol. 8, no. 2, p. 146, 2020.

[10] M. Obstfeld and K. S. Rogoff, "Global current account imbalances and exchange rate adjustments," Brookings Papers on Economic Activity, vol. 2005, no. 1, pp. 67-146, 2005.

[11] C. Tille and E. V. Wincoop, "Solving dsge portfolio choice models with dispersed private information," Journal of Economic Dynamics and Control, vol. 40, pp. 1-24, 2014.
[12] R. J. Caballero, E. Farhi, and P.-O. Gourinchas, "An equilibrium model of "global imbalances" and low interest rates," The American Economic Review, vol. 98, no. 1, pp. 358-393, 2008.

[13] E. G. Mendoza, V. Quadrini, and J. V. Ríos-Rull, "Financial integration, financial development, and global imbalances," Journal of Political Economy, vol. 117, no. 3, pp. 371-416, 2009.

[14] A. Pavlova and R. Rigobon, "An asset-pricing view of external adjustment," Journal of International Economics, vol. 80, no. 1, pp. 144-156, 2010.

[15] P.-O. Gourinchas, H. Rey, and K. Truempler, "The financial crisis and the geography of wealth transfers," Journal of International Economics, vol. 88, no. 2, pp. 266-283, 2012.

[16] G. Georgiadis and A. Mehl, "Financial globalisation and monetary policy effectiveness," Journal of International Economics, vol. 103, pp. 200-212, 2016.

[17] K. S. Rogoff and T. Tashiro, "Japan's exorbitant privilege," Journal of the Japanese and International Economies, vol. 35, pp. 43-61, 2015.

[18] P. O. Gourinchas and H. Rey, "International financial adjustment," Journal of Political Economy, vol. 115, no. 4, pp. 665-703, 2007.

[19] S. E. Curcuru, T. Dvorak, and F. E. Warnock, "Decomposing the U.S. External returns differential," Journal of International Economics, vol. 80, no. 1, pp. 22-32, 2010.

[20] X. Fan, W. Wang, and L. Xiao, "Gravity model analysis of international equity portfolio investment," The Journal of World Economy, vol. 35, no. 7, pp. 42-65, 2012.

[21] L. Xiao and B. Wang, "Global imbalances and China's net external assets: analysis from the perspective of financial development," The Journal of World Economy, vol. 34, no. 2, pp. 57-86, 2011.

[22] F. Ghironi, J. Lee, and A. Rebucci, "The valuation channel of external adjustment," Journal of International Money and Finance, vol. 57, pp. 86-114, 2015.

[23] H. Nguyen, "Valuation effects with transitory and trend productivity shocks," Journal of International Economics, vol. 85, no. 2, pp. 245-255, 2011.

[24] C. Tille and E. van Wincoop, "International capital flows," Journal of International Economics, vol. 80, no. 2, pp. 157-175, 2010.

[25] P. Benigno and F. Romei, "Debt deleveraging and the exchange rate," Journal of International Economics, vol. 93, no. 1, pp. 1-16, 2014.

[26] P. R. Lane and G. M. Milesi-Ferretti, "The external wealth of nations: measures of foreign assets and liabilities for industrial and developing countries," Journal of International Economics, vol. 55, no. 2, pp. 263-294, 2001.

[27] A. S. Bénétrix and P. R. Lane, "Fiscal cyclicality and emu," Journal of International Money and Finance, vol. 34, pp. 164-176, 2013.

[28] M. B. Devereux and A. Sutherland, "Valuation effects and the dynamics of net external assets," Journal of International Economics, vol. 80, no. 1, pp. 129-143, 2010.

[29] W. Liu, X. Huang, and J. Chen, "Financial development, valuation effect and external imbalance adjustment-a comparative study on two financial channels," Journal of International Trade, vol. 1, pp. 164-174, 2018.

[30] L. Xiao and S. Chen, "China's international investment position and the role of valuation channel in external imbalance adjustments," Economic Research Journal, vol. 48, no. 7, pp. 20-34, 2013. 
[31] Q. Yang and N. Bao, "Valuation effect and structural analysis of brics: 1970-2015," Word Economy Studies, vol. 10, pp. 93-110, 2017.

[32] X. Li and X. Zhou, "Sustainability of American external debt: extension of external adjustment theory," The Journal of World Economy, vol. 35, no. 12, pp. 130-155, 2012.

[33] S. Gygli, F. Haelg, N. Potrafke, and J.-E. Sturm, "The KOF globalisation index - revisited," The Review of International Organizations, vol. 14, no. 3, pp. 543-574, 2019.

[34] N. Coeurdacier, R. Kollmann, and P. Martin, "International portfolios, capital accumulation and foreign assets dynamics," Journal of International Economics, vol. 80, no. 1, pp. 100-112, 2010.

[35] P. R. Lane and G. M. Milesi-Ferretti, "The external wealth of nations mark II: revised and extended estimates of foreign assets and liabilities, 1970-2004," Journal of International Economics, vol. 73, no. 2, pp. 223-250, 2007.

[36] Z. Lv, H. Wang, and Y. Zhao, "Measurement and comparison of international economic openness," Journal of International Trade, vol. 1, pp. 14-24, 2015.

[37] J. Galí and T. Monacelli, "Understanding the gains from wage flexibility: the exchange rate connection," The American Economic Review, vol. 106, no. 12, pp. 3829-3868, 2016.

[38] H. Amiri, M. Sayadi, and S. Mamipour, "Oil price shocks and macroeconomic outcomes; fresh evidences from a scenariobased nk-dsge analysis for oil-exporting countries," Resources Policy, vol. 74, Article ID 102262, 2021.

[39] J. D. M. Fisher, "The dynamic effects of neutral and investment-specific technology shocks," Journal of Political Economy, vol. 114, no. 3, pp. 413-451, 2006. 